This report was prepared as an account of work sponsored by an agency of the United States Government. Neither the United States Government nor any agency thereof, nor any of their employees, makes any warranty, express or implied, or assumes any legal liability or responsibility for the accuracy, completeness, or usefulness of any information, apparatus, product, or process disclosed, or represents that its use would not infringe privately owned rights. Reference herein to any specific commercial product, process, or service by trade name, trademark, manufacturer, or otherwise does not necessarily constitute or imply its endorsement, recommendation, or favoring by the United States Government or any agency thereof. The views and opinions of authors expressed herein do not necessarily state or reflect those of the United States Government or any agency thereof.

WSRC-MS- $-90-322$

DE92 015321

\title{
TRITIUM DISTRIBUTION IN THE ENVIRONMENT IN THE VICINITY OF A CHRONIC ATMOSPHERIC SOURCE-ASSESSMENT OF THE STEADY STATE HYPOTHESIS (U)
}

by

C. E. Murphy, Jr., L. R. Bauer, and C. C. Zeigler

Westinghouse Savannah River Company

Savannah River Laboratory

Aiken, South Carolina 29808

A paper proposed for presentation at the

4th Topical Meeting on Tritium Technology in Fission, Fusion, and
Isotopic Applications

Albuquerque, New Mexico

September 30 - October 4, 1991

and for publication in the proceedings

This paper was prepared in connection with work done under Contract No. DE-AC09-89SR18035 with the U.S. Department of Energy. By acceptance of this paper, the publisher and/or recipient acknowledges the U.S. Government's right to retain a nonexclusive, royalty-free license in and to any copyright covering this paper, along with the right to reproduce and to authorize others to
reproduce all or part of the copyrighted paper. 
TRITIUM DISTRIBUTION IN THE ENVIRONMENT IN THE VICINITY OF A CHRONIC ATMOSPHERIC SOURCE - ASSESSMENT OF THE STEADY STATE HYPOTHESIS

\author{
C.E. Murphy Jr., L.R. Bauer, and C.C. Zeigler \\ Westinghouse Savannah River Company \\ Aiken, South Carolina 29808
}

\begin{abstract}
The Savannah River Site (SRS) is a major radionuclide production center. Tritium has been released to the atmosphere over the 36 year period of operation. The tritiated water concentration of the atmosphere, rain, vegetation and food have been routinely monitored during this period. Special studies have been made of tritium in soils and in the organic fractions of these same materials. The available data suggest that the average tritium concentration in the components of the terrestrial environment have approached a steady state with the two main sources of tritium, rainfall and atmospheric water vapor.
\end{abstract}

\section{INTRODUCTION}

The Savannah River Site is a major tritium production facility for National Defense. Operations that produce and handle tritium at the SRS result in the release of some tritium to the environment. Tritium has been released from the heavy water moderated production reactors, from the separation of fuel and targets for recovery of transuranic isotopes, from separation and processing of tritium, from heavy water rework, and from research operations. The majority of the releases have been to the atmosphere. Sinaller amounts have been released to streams and to the ground by way of open seepage basins.

Tritium has been released to the atmosphere as tritiated water vapor and tritiated hydrogen gas. A small amount of tritium (less than $1 \%$ ) has also been released as tritiated methane. Most of the tritium is released through elevated stacks, though a small amount enters the atmo- sphere through evaporation from the surface of the seepage basins.

Fig. 1 illustrates the annual tritium releases categorized by origin. In most years the majority of the tritium is released from the separations areas, largely from the tritium works. The other major component is direct release from the reactor areas through the stack system. The small component from other sources includes releases from seepage basins, from research facilities, and from the fuel processing area. The atmospheric tritium releases are divided between $27.3 \%$ from reactor areas, $72.2 \%$ from the separations area and $0.5 \%$ from all other areas.

\section{ANNUAL AVERAGE TRITIATED WATER CONCENTRATIONS}

Measurements of tritium content of atmospheric water vapor have been made since the early 1960 s at a network of monitoring stations at

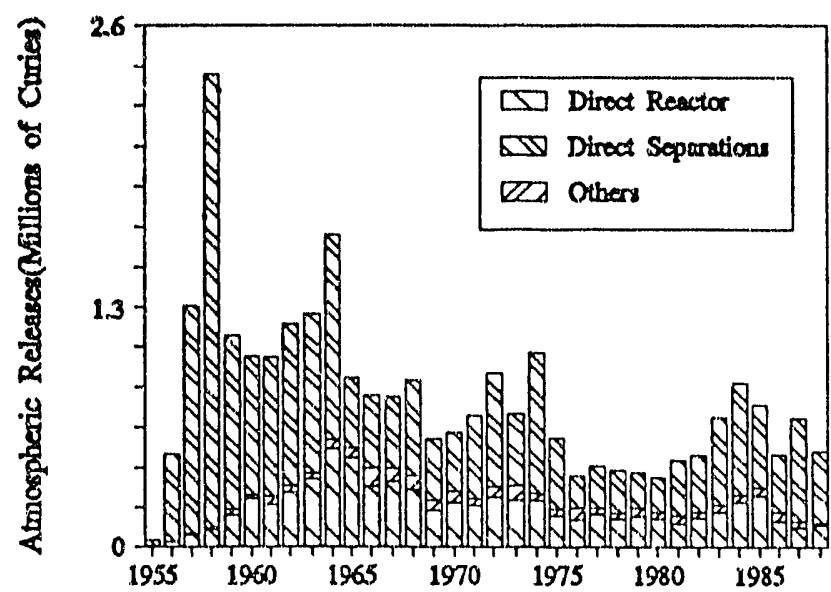

Fig. 1. Sources of Atmospheric Tritium Releases at SRS. 
SRS. The averagc annual concentrations are from the semiannual and annual reports of the SRS Health Protection Department.

The majority of the monitoring stations are located in two rings around the site. The inner ring is approximately $15 \mathrm{~km}$ from the center of SRS, and the outer ring is $40 \mathrm{~km}$ from the center. The concentrations around each ring are within a factor of two for most locations in most years. Fig. 2 shows isopleths of the average concentration of tritiated water in air and the inverted wind rose for the 5-year period from 1982 through 1986 (points are in the direction which the wind is going rather than the normally reported direction the wind is coming from). The slightly greater tritium concentration in the east and west directions and the lower tritium concentration to the south are mirrored by the frequency of wind blowing in these directions.

The spread of tritium in the atmosphere is restricted to the volume of air between the ground surface and the height of the surface mixing layer. At the top of this layer, mixing is suppressed by a sudden increase in temperature (an inversion).

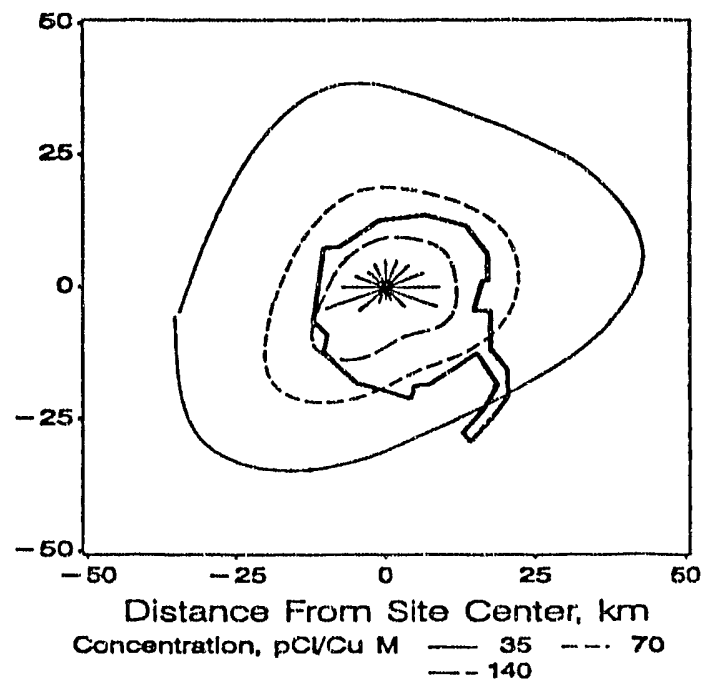

Fig. 2. The Directional Distribution of Tritiated Water Vapor in the Vicinity of SRS.

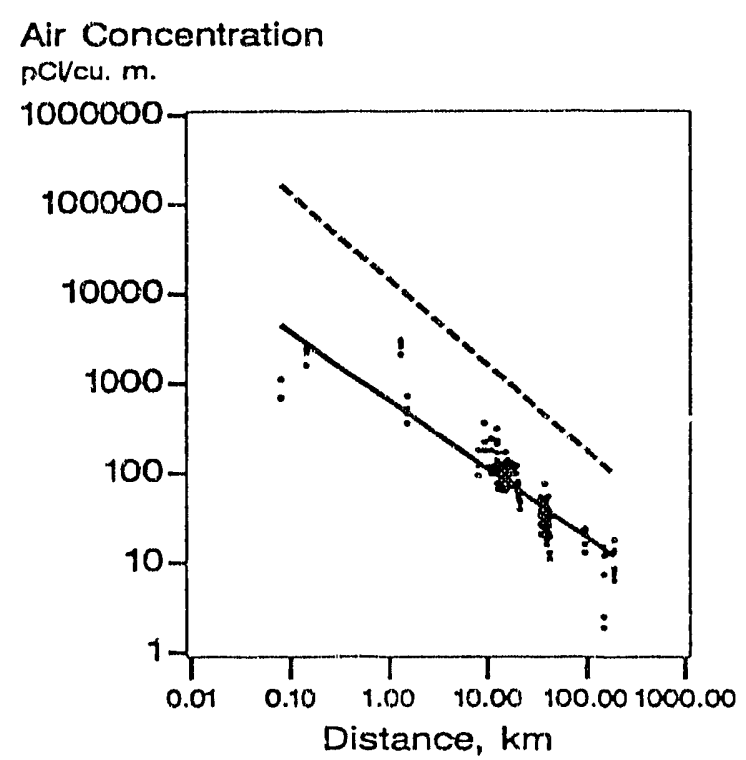

Fig 3 Decrease in Average (1982-1986) and Maximum Air Tritiated Water Concentration with Distance from the Center of SRS.

When the gas has spread to the height of the mixing layer, it is further diluted only by horizontal mixing.

Once the gas has spread through the volume of air in the mixing layer, the gas concentration averaged over circular arcs around the release point will decrease at a rate that is proportional to the inverse of the distance from the release point. The further the gas moves from the release point the greater the volume of air in which it will mix and the faster its concentration will decrease. When dispersion is occurring in this manner, the tritium concentation will be distributed along a straight line when plotted against the distance to the sampling station on a logarithmic scale.

rig. 3 shows the annual average air concentration at each monitoring station during the 5 -yr period from 1982 to 1986 plotted against the distance from the center of the site. The lower, solid line is drawn through the annual average 
concentrations while the upper dashed line represents the level at each distance which is calculated to lie above $95 \%$ of the measured maximums.

The tritium concentration for a set of measurements taken over a specific period of time can be characterized (i.e. approximately reproduced) by the concentration at any arbitrary point on this line and the slope of the line. The straight line drawn on Fig. 3 can be characterized by an air concentration of $66 \mathrm{pCi} / \mathrm{m}^{3}$ at $20 \mathrm{~km}$ and a slope of -0.76 . The $20-\mathrm{km}$ distance is outside, but near, the SRS boundary. The negative slope indicates that the concentration is decreasing as the air is sampled at increasing distances from SRS. The releases for all the year's when data were collected can be characterized in this way and compared to each other or to factors which are thought to have influenced the concentrations measured in a particular year.

In Fig. 4 the average concentration at $20 \mathrm{~km}$ is plotted against the total tritium releases for each year. Most of the releases to the atmosphere come from the tritium production area, the chemical separations plant, or the reactor areas. Tritium from the reactor and chemical separation areas is almost entirely in the form of tritiated water vapor. Tritium from the tritium production area has been primarily, but not totally, in the form of tritiated hydrogen. Since the sampling monitors collect tritiated water only, the air concentration measured should respond to the releases of the separations and reactor aren? plus some fraction of the tritium production area releases.

The lower line in Fig. 4 shows that an estimate of the tritiated water vapor released based on a statistical best estimate of the fraction of tritiated water vapor from the tritium production area has less scatter than the data plotted against the total releases. The best estimate of tritiated water vapor releases from the tritium production area determined by statistical regression is $15 \%$ of the total tritium released.

The fraction of tritiated water released is close to the value of $16 \%$ that was determined when the chemical forms of tritium were measured during a few years experiencing no large, unplanned tritiated hydrogen releases. However, measurements of tritium forms during a more recent 5-yr period, which included unplanned releases, suggest that the average for those years was nearer $35 \%$ HTO.

From this analysis it is evident that the major factors determining the annual average tritiated water vapor concentration of the atmosphere around SRS are the distance from the source and the amount of tritium released. The height of the atmosphere through which the release is mixed and the wind speed also affect the concentration. Although the variation in the annual average values of these factors is not great, it may explain some of the variation in the measured concentrations not accounted for by distance from the site and the quantity of tritium released in a given year. It appears reasonable to conclude that the transport

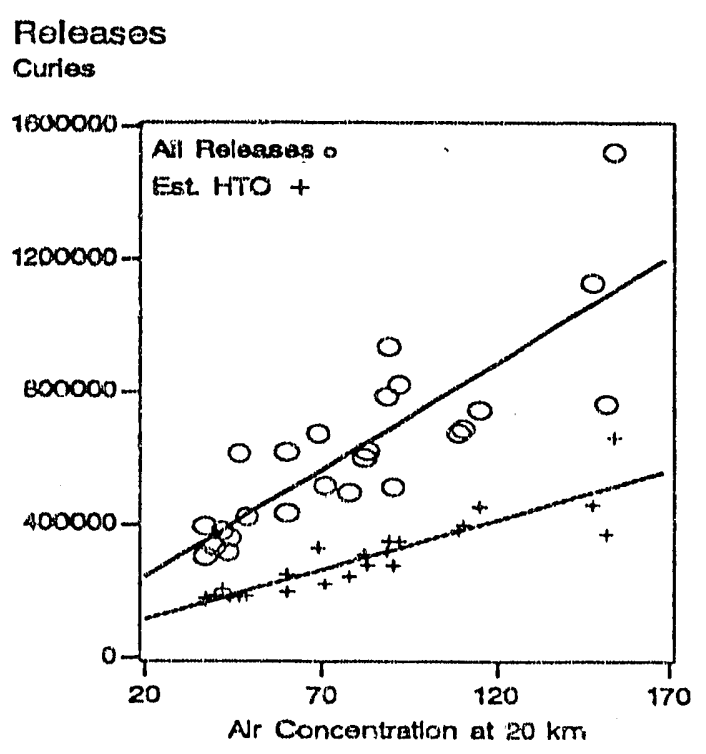

Fig. 4 The Effect of Releases on the Concentration of Tritiated Air Water Vapor. 
of tritiated water vapor in the atmosphere is well understood under SRS conditions.

\section{DEPOSITION OF TRITIUM}

Deposition of a gas is the sum of the processes that remove it from the air and deposit it on the soil, vegetation, water, or other surfaces of the earth. Deposition processes are usually classified as wet or dry, depending on whether precipitation is involved in the deposition process. One of the dominant factors determining the deposition rate is the concentration of the gas in the air above the surface. Therefore, the spatial distribution of the deposited material is usually similar to the distribution of the gas concentration in the air.

\section{Deposition of Tritiurn in Rain Water}

Rainfall is collected and analyzed for tritium at most of the air monitoring locations. The tritium concentration in rain water decreases with distance from the center of the site in the same manner as tritiated water vapor and can be approximated by a straight line when plotted logarithmically. The slope of the line for the same 5-yr period used in Fig. 2 is -0.76 , which is identical to the slope of the air concentration. As indicated by Fig. 5 , the radial distribution of tritium in rain water at $20 \mathrm{~km}$ is very similar to the distribution of air tritiated water concentration. However, the concentration of rain water is less than that of air water vapor.

Some of the difference between rain water and air water vapor concentrations can be explained by considering the difference in the way the concentrations are measured. Air tritiated water vapor is reported as an averaged sample collected over a 2-weeks. The rainwater is collected over the same period, but rainfall takes place during only a small part of this time. Thus the rainwater concentration is the result of the air concentration during a small part of the measurement period.
The average equilibrium and its variation from year to year can be determined independent of the variation caused by the decrease in concentration with distance by taking the ratios of the concentrations of air water and rainwater at $20 \mathrm{~km}$. Analysis shows that there is considerable variation among years, with the maximum of $56 \%$ of equilibrium, a minimum of $20 \%$, and an average of $39 \%$.

\section{Deposition of Tritium to Soil}

Deposition of tritium to the soil is the result of the interaction of a number of processes. Atmospheric releases reach the soil by rainout of tritiated water, deposition of tritiated water vapor ${ }^{1}$, and deposition and oxidation of tritiated hydrogen gas. $^{2}$

After deposition, most of the tritium is in the water form and moves with the bulk of the soil water by miscible displacement as it infiltrates deeper into the soil. Water is also absorbed by the roots of vegetation and reenters the atmosphere by transpiration from the plants. ${ }^{3}$

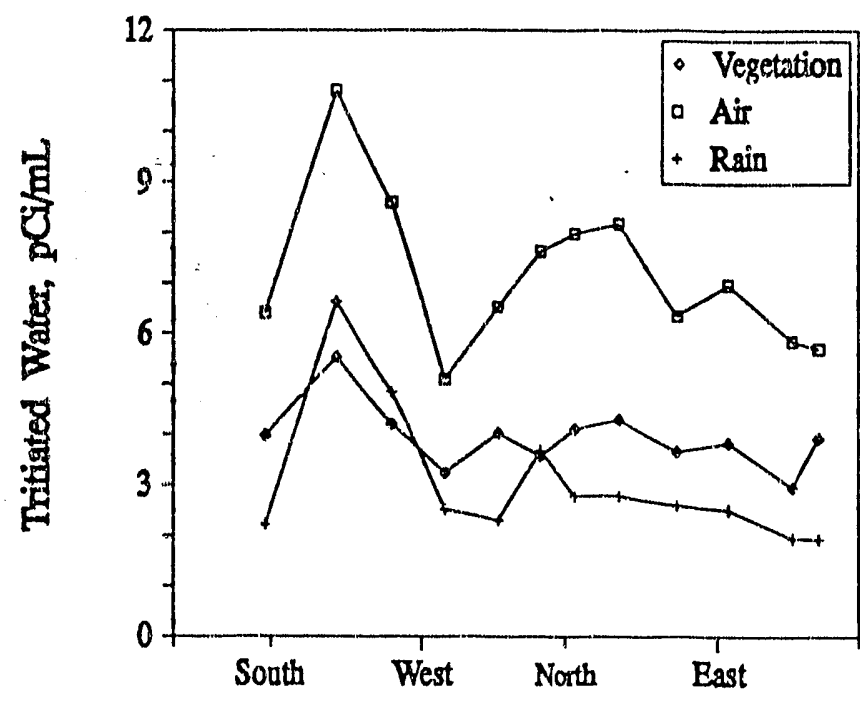

Fig. 5 A Comparison of the Concentration of Tritium in Air Rainwater and Vegetationin Different Directions from the Center of SRS at $20 \mathrm{~km}$ 
Routine measurements are not made of soil tritium but the soil tritium content is reflected in the vegetation tritium concentration, which is measured. The vegetation tritiated water comes, partially, from absorption of soil water.

Soil tritium concentrations have been measured as part of special programs to study this part of the tritium cycle. The results of measurements made by Sweet and Murphy in 1979 and 1980 indicated that the tritium content in soil water decreased with distance from the site center. ${ }^{4}$ The average concentrations are similar to those found in rainwater, which are lower than those found in the atmosphere. The concentration of tritiated water in soil approaches or excedes that in the atmosphere only during or immediately after exposure to large releases of tritiated hydrogen.

\section{Tritium Concentration in Vegetation}

The tritiated water content of the vegetation follows the same general pattern of decrease with distance from the center of SRS as air, soil, and rainwater tritiated water. For the 5-year period from 1982 to 1986, the characteristic tritiated water concentration of the vegetation at $20 \mathrm{~km}$ is $3.3 \mathrm{pCi} / \mathrm{mL}$ and the slope is -1.01 .

The average concentration is between that of the air moisture and rainwater. This is consistent with the steady-state balance between uptake of water from the soil and diffusive exchange with tritiated water vapor in the atmosphere. ${ }^{5}$ In most years this results in an average vegetation water tritium concentration greater than the soil concentration but less than the air moisture concentration (Fig. 5). This can be reversed during periods of deposition of tritiated hydrogen gas. ${ }^{6}$

\section{TRITIATED WATER IN FOOD}

Tritium is measured in a variety of crops and animal food products grown in the vicinity of SRS. Milk is collected at local farms and from one major milk distributor which gets its milk from the area surrounding SRS. Four vegetable food types were monitored from 1971-1987; collard greens, fruit (plums, apples, or peaches), grains (wheat, rye, or barley), and corn. Four animal food types were also measured during the same period; beef, eggs, chicken, and pork.

The water concentration in the aerial parts of plants is determined by both the atmospheric and soil tritiated water concentration. In animals the main components of the tritium balance are the inhalation of air moisture and drinking water, with drinking water the dominant factor.

The results of the measurements of tritium in food in the vicinity of SRS indicate that the concentration in food is very similar to the concentration in environmental water (Fig. 6). The small sample size and scatter in the data preclude determining a definitive value of the ratio of tritium concentration in food and either rainfall or air moisture.

\section{ORGANIC TRITIUM}

Long-term monitoring data of organic tritium concentrations in the SRS environment are not

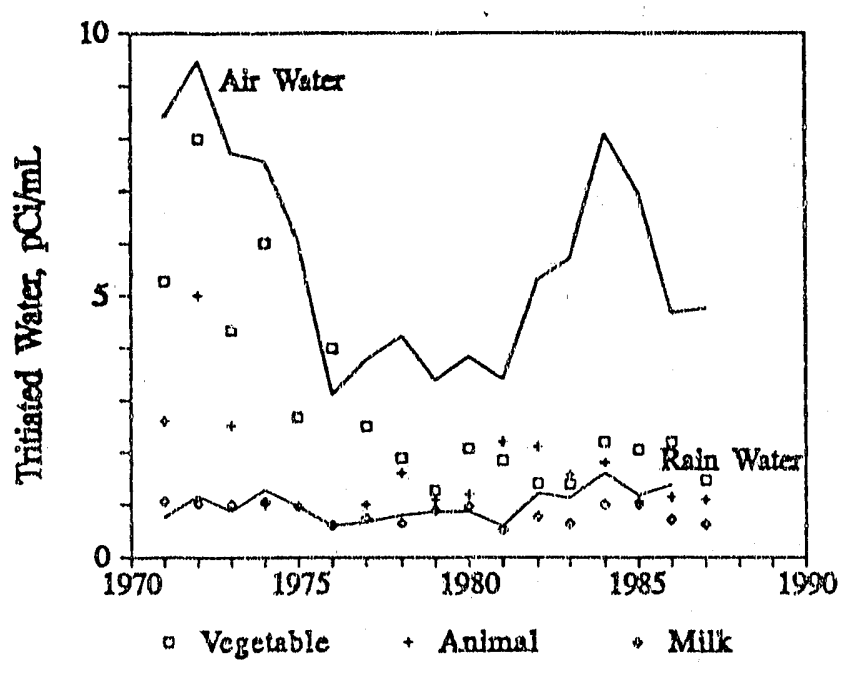

Fig. 6 The Tritiated Water Concentration in Foods Collected in the Vicinity of SRS. 


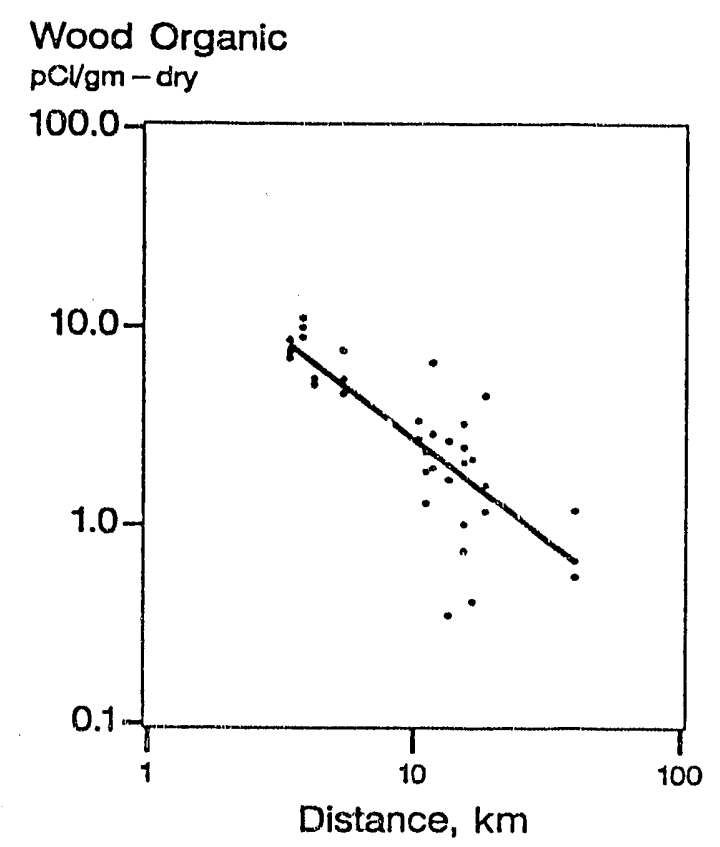

Fig. 7 The Decrease in the Tritium Concentration of Wood Organic Material with Distance from the Center of SRS

available. A few short-term studies provide some information about the concentrations in soil, vegetation, and wildlife.

The specific activity of tritium in the organic faction of soil has been found to average somewhat higher than the water in the soil. No concentrating factor has been demonstrated in the soil; the reason for the higher concentration appears to be related to the source of the organic matter which is the vegetation growing in the soil.

Sanders ${ }^{7}$ measured the tritium content of growth rings in pine trees. He analyzed rings grown during 1960, 1965, and 1970. The tritium concentration in the rings show the characteristic decrease with distance from SRS (Fig. 7). This is expected because the tritium in the wood is synthesized by the tree from the water in its leaves. ${ }^{9}$ As indicated previously the average tritiated water concentration of the leaves is greater than rainwater but less than atmospheric moisture. This may explain why the soil organic tritium, which is derived from leaf water, is greater than the soil water, which is largely derived from rain.

The only other source of data on organic tritium at SRS is from the annual deer hunts. In 1966, Evans ${ }^{9}$ conducted a detailed study of the relationship of tritiated water to the organic fraction of deer. Samples were taken of various organs, and after the water was removed, the organs were burned and the water of combustion compared to the free water in the deer. He found that the tritium content of the deer organs was always near that of the free water (Fig. 8). The comparatively low ratio of tritium in fat to tritium in the body water results from the few exchangeable hydrogen sites in this class of compounds. ${ }^{10}$

\section{CONCLUSIONS}

The available data suggest that the average tritium concentration in the components of the terrestrial environment have approached a steady state with the two main sources of tritium, rainfall

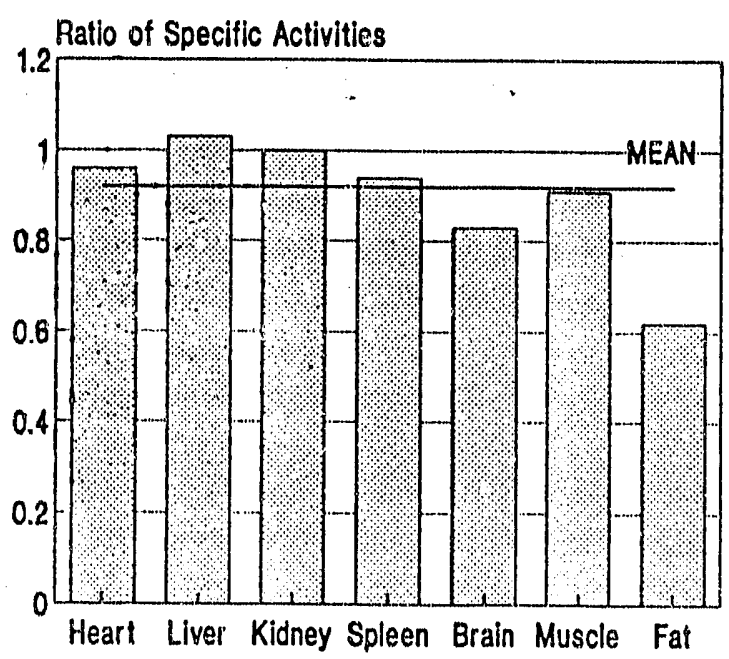

Fig. 8 The Ratio of Organic Tritium to Tritiated Water in Individual Organs for Deer Collected During 1966 Hunting Season 
and atmospheric moisture. The tritiated water concentration of most components is greater than the average concentration of rainwater but lower than the average concentration of atmospheric moisture. The only exception appears to occur following relatively large releases of tritiated hydrogen when deposition to the soil elevates the soil moisture concentration.

\section{REFERENCES}

1. J. A. Garland and L. C. Cox. "The Absorption of Tritium Gas by English Soils and Plants and the Sea Water," Air and Soil Pollution 14:103114 (1980).

2. C. E. Murphy, Jr. A. L. Boni, and S. P. Tucker. The Conversion of Gaseous Molecular Tritium to Tritiated Water in Biological Systems, DP1422, E. I. du Pont de Nemours \& Co., Savannah River Laboratory, Aiken, SC (1976).

3. Y.Belot, J. Guenot, and C. Caput. "Emission to Atmosphere of Tritiated Water Formed at Soil Surface by Oxidation of HT," Fusion Technology 14(2):1231-1234 ( 1988); , B. Wiener, M. Taschner, and C. Bunnenberg. "HTO Reernission from Soil after HT Deposition and Dose Consequences of HT Releases," Fusion Technology 14(2):1247-1252 ( 1988).

4. C. W. Sweet and C. E. Murphy, Jr. "Tritium Deposition in Pines and Soil from Atmospheric Releases of Molecular Tritium," Environ. Sci. Tech. 18:358-361 (1984); C. W. Sweet and C. E. Murphy, Jr. "Oxidation of Molecular Tritium by Intact Soils, "Environ. Sci.Tech. 15:1485-1487 (1981).

5. F. Raney and Y. Vaadia "Movement and Distribution of THO in Tissue Water and Vapor Transpired by Shoots of Helianthus and Nicotiana". Plant Phys, 40:383-388; Y. Belot, D. Ganthier, H. Camus, and C. Caput. "Prediction of the Flux of Tritiated Water from the Air to
Plant Leaves," Health Phys. 37, 575-583 (1979); C.E. Murphy, Jr. "The Relationship Between Tritiated Water Activities in Air, Vegetation, and Soil UnderSteady-State Conditions, "Health Phys. 47(4), 635-639 (1984).

6. G.L. Ogram, F.S. Spencer and R.M. Brown "Field Studies of HT Behavior in the Environment," The interaction with Soil. Fusion Tech. 14(2): 1170-1175 (1988)

7. S. M. Sanders Non-labile Tritium in Savannah River Plant Pine Trees, DP-1407, E. I. du Pont de Nemours \& Co., Savannah River Laboratory, Aiken, SC (1976).

8. Y. Belot, J. Guenot, C. Caput, and F. Bourdeau. "Incorporation of Tritium into Organic Matter of Terrestrial Planis Exposed to Tritiated-Water Releases of Short Duration, "Health Physics 44:666-668 (1983).

9. A.G. Evans, "New Dose Estimates from Chronic Tritium Exposures," Health Phys. 16(1):57-63 (1969).

10. J. van den Hoek, R. Kirchman, and N.B. Juan. 1979. "Transfer and Incorporation of Tritium in Mammals," in Behavior of Tritium in the Environment, IAEA, Vienna. 

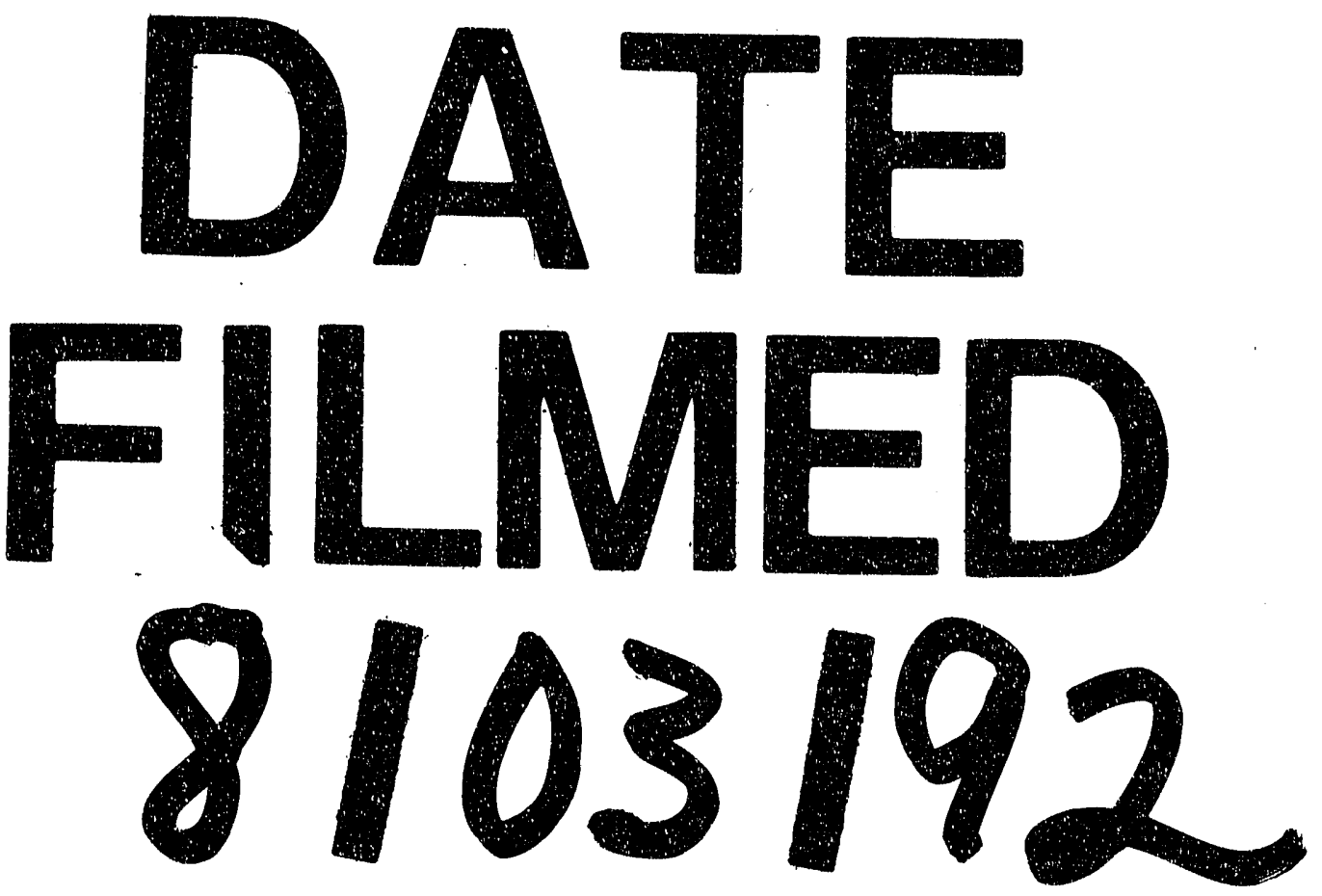

$\overline{1}$ 


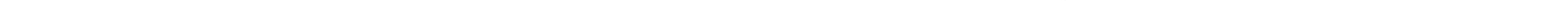

